\title{
Redescription of Ochmacanthus batrachostoma (Miranda-Ribeiro, 1912) (Siluriformes: Trichomycteridae): a possible case of incipient paedomorphism
}

\author{
Caio S. Neto and Mário de Pinna
}

The lepidophagous stegophiline catfish Ochmacanthus batrachostoma (Miranda-Ribeiro, 1912) is endemic to the ParanáParaguai basin and is the only member of its genus in that drainage. It remains a poorly-known taxon mainly due to the historical scarcity of study specimens. The species is herein redescribed on the basis of type and non-type specimens from Brazil, Argentina and Paraguay. Ochmacanthus batrachostoma can be distinguished from congeners by the presence of long maxillary and rictal barbels, reduction of the posterior end of the caudal peduncle, a tadpole-like caudal fin and peduncle, among other morphometric traits and features of internal anatomy. Comparisons show that a number of unique traits of adult $O$. batrachostoma resemble conditions seen in juvenile specimens of other members of Stegophilinae. Such traits are also more pronounced in juveniles of $O$. batrachostoma itself. The species also has the smallest maximum body size in Ochmacanthus and among the smallest of any stegophiline. In combination, such observations suggest that the species is paedomorphic, although to a degree less extreme than seen in some other trichomycterids. This is the first possible case of paedomorphosis identified for stegophilines.

O bagre lepidofágico Stegophilinae Ochmacanthus batrachostoma (Miranda-Ribeiro, 1912) é endêmico da bacia ParanáParaguai e é único membro do gênero presente na drenagem. Permanece um táxon pouco conhecido principalmente devido à escassez histórica de espécimes para estudo. A espécie é aqui redescrita com base em espécimes tipo e não tipo provenientes do Brasil, Argentina e Paraguai. Ochmacanthus batrachostoma pode ser diferenciado dos congêneres pela presença de longos barbilhões maxilares e rictais, extremidade posterior do pedúnculo caudal reduzida, nadadeira e pedúnculo caudal com forma semelhante a cauda de um girino, além de outras características morfométricas e da anatomia interna. Comparações mostram que certas características exclusivas do adulto de $O$. batrachostoma se assemelham às condições observadas nos espécimes juvenis de outros Stegophilinae. Essas características são mais pronunciadas nos próprios juvenis de $O$. batrachostoma. A espécie também apresenta o menor comprimento corporal máximo entre os congêneres e é um dos menores Stegophilinae. Em combinação, essas observações sugerem que a espécie é pedomórfica, mas em grau menos extremo do que observado em outros trichomicterídeos. Esse é o primeiro caso possível de pedomorfose identificado em Stegophilinae.

Keywords: Juvenile, Paraná-Paraguai drainage, Paedomorphosis, Stegophilinae, Taxonomy.

\section{Introduction}

Trichomycteridae is the second most species-rich family in the freshwater superfamily Loricarioidea, with 280 valid species in 41 genera and eight subfamilies (de Pinna, 1998; Eschmeyer \& Fong, 2014), distributed throughout major river drainage basins from Costa Rica to Patagonia, on both sides of the Andes (de Pinna \& Wosiacki, 2003; Datovo $\&$ de Pinna, 2014). Most trichomycterids do not surpass $100 \mathrm{~mm}$ in standard length and feed on small invertebrates (Machado \& Sazima, 1983; de Pinna \& Wosiacki, 2003; Fernández \& Schaefer, 2009). However, those belonging to subfamilies Vandellinae and Stegophilinae have striking semi-parasitic habits. The former includes only hematophagous species and the latter includes species that feed on mucus, skin and scales of other fish, usually in combination (Machado \& Sazima, 1983; Winemiller \& Yan, 1989; Zuanon \& Sazima, 2004, 2005; Leung, 2014). Such highly-specialized feeding habits are matched by extraordinary modifications of the feeding apparatus such as the large number of teeth arranged in regular rows, oral opening as a sucking disk, in combination with the presence of odontodes on the opercular apparatus typical of most trichomycterids (de Pinna, 1998; Adriaens et al., 2010). The semi-parasitic forms of the Trichomycteridae are popularly known as candirus.

Museu de Zoologia da Universidade de São Paulo, Departamento de Ictiologia, Caixa Postal 42494, 04218-970 São Paulo, SP, Brazil. (CSN) caiosantosnt@gmail.com (corresponding author), (MCCP) pinna@usp.br 
Ochmacanthus is one of 11 genera of Stegophilinae. The subfamily has 28 valid species currently recognized (DoNascimiento, 2013, 2015; Eschmeyer \& Fong, 2014) distributed throughout the drainage basins of the Amazon, Orinoco, São Francisco, Paraná-Paraguai, Atlântico Sul and Uruguay rivers (Koch, 2002). The group is traditionally characterized by a large number of fine teeth arranged in regular rows and by the modification of the oral opening into a semi-circular sucking disc (Baskin, 1973; de Pinna, 1998; DoNascimiento, 2012). Despite their fascinating biological properties, the systematics of Stegophilinae is still poorly known.

Ochmacanthus currently includes five valid species (DoNascimiento, 2013, 2015; Eschmeyer \& Fong, 2014). It is easily distinguished from other stegophiline genera by the pronounced compression of the caudal peduncle, which is also expanded dorsally and ventrally by numerous large accessory caudal-fin rays (Baskin, 1973; DoNascimiento, 2015). Eigenmann (1912) described Ochmacanthus with only one species, O. flabelliferus. Three months later, Miranda-Ribeiro (1912) described the genus Gyrinurus along with its single species, Gyrinurus batrachostoma. In 1918, Eigenmann synonymized Gyrinurus under Ochmacanthus (though retaining the former as a subgenus and its sole species as valid) and included Stegophilus reinhardtii Steindachner, 1882 therein. Myers (1927) described two additional species of Ochmacanthus, $O$. alternus and $O$. orinoco from the Río Orinoco drainage. The most recent study of phylogenetic relationships within Stegophilinae considered Ochmacanthus as monophyletic, and as sister-group to Haemomaster (DoNascimiento, 2013, 2015).

Since Eigenmann (1918), there has been practically no additional information published on Ochmacanthus batrachostoma. The species has not been in included in more recent and general papers on trichomycterid systematics because of a lack of study material. Its description from a single specimen was made more than a century ago, and is severely outdated. The morphology of the species remains poorly known, and its mention in the literature is restricted to catalogues, checklists, faunistic lists or range extensions.

Herein, we redescribe Ochmacanthus batrachostoma from newly collected and previously-available material. Our taxonomic account includes new data on morphology, intraspecific variation and geographical distribution. We also include a discussion on incipiently paedomorphic traits in $O$. batrachostoma, which may be the first such case reported for stegophilines.

\section{Material and Methods}

The holotype and 27 additional alcohol-preserved or cleared and stained (c\&s) specimens were examined. Morphometric measurements were taken according to standards normally followed in trichomycterid taxonomy (Tchernavin, 1944), with some modifications to fit morphological modifications typical of stegophilines (e.g., following de Pinna \& Britski, 2001; DoNascimiento \& Provenzano, 2006; DoNascimiento, 2012). All measurements were straight-line, taken with digital calipers to the nearest $0.1 \mathrm{~mm}$. Measurements are expressed as proportions of standard length (SL), except for subunits of the head, which are expressed as proportions of head length and the depth of the distal end of the caudal peduncle, which is given as proportion of body depth at the vertical through the posterior end of dorsal fin. Cephalic pore nomenclature follows Arratia \& Huaquin (1995). Meristics follow Baskin (1973) and de Pinna \& Britski (1991). In the caudal fin counts, the first number indicates the number of principal rays on the dorsal lobe and the second the numbers of principal rays on the ventral lobe. Counts of vertebrae and pleural ribs were taken from c\&s specimens and digital radiographs. Counts of haemal arches were taken only from c\&s specimens. Cleared and stained preparations were done according to Taylor \& Van Dyke (1985).

Institutional abbreviations are: Academy of Natural Sciences of Drexel University (ANSP), Philadelphia (formerly Academy of Natural Sciences of Philadelphia); Field Museum of Natural History (FMNH), Chicago; Museu Nacional do Rio de Janeiro (MNRJ), Rio de Janeiro; Museu de Zoologia da Universidade de São Paulo (MZUSP), São Paulo; Coleção Ictiológica do Núcleo de Pesquisas em Limnologia, Ictiologia e Aquicultura da Universidade Estadual de Maringá (NUP), Maringá; Royal Ontario Museum (ROMICH), Ontario; Senckenberg Forschungsinstitut und Naturmuseum (SMF), Frankfurt; Universidad Central de Venezuela (UCV), Caracas; University of Michigan Museum of Zoology (UMMZ), Ann Arbor; National Museum of Natural History, Smithsonian Institution (USNM), Washington, D.C.

\section{Results}

Ochmacanthus batrachostoma (Miranda-Ribeiro, 1912) Figs. 1-2

Gyrinurus batrachostoma Miranda-Ribeiro, 1912:28, pl. (type-locality: Brazil, Mato Grosso, Corumbá, rio Paraguai at São Luiz de Cáceres. Holotype: MNRJ 786).

Ochmacanthus batrachostoma. -Eigenmann, 1918:511 [generic reallocation]. -Gosline, 1945: 65 [catalogue]. -Eschmeyer, 1990:273 [catalogue]. -Casciotta \& Almirón, 1996: 25 [occurrence in rio Paraná, Argentina]. -Winemiller, 1996: 109 [ecological notes]. -Eschmeyer et al., 1998: 204 [catalogue]. -de Pinna \& Wosiacki, 2003: 276 [checklist]. -Ferraris et al., 2007: 409 [checklist]. -DoNascimiento, 2012: 487 [general comments]. -Santos Neto, 2014 [generic revision, phylogenetic position]. 
Diagnosis. Ochmacanthus batrachostoma is easily distinguished from remaining species of its genus by any of the following characters: presence of long maxillary and rictal barbels ( $v s$. short barbels), the former reaching the base of the pectoral fin and the latter more than half that length (vs. maxillary barbel not reaching beyond the interopercular patch of odontodes and rictal barbel not longer than the associated labial fold); the caudal peduncle expanded into a paddle-like shape by numerous large procurrent rays, with markedly convex dorsal and ventral profiles (vs. caudal peduncle approximately rectangular in shape, with straight or gently convex dorsal and ventral profiles); the muscular portion of the caudal peduncle tapering markedly posteriorly (vs. tapering gently to caudal fin ), so that its posterior depth is $20-25 \%$ of its anterior depth ( $v s$. more than $25 \%$ ); the caudal fin shorter than $10 \%$ of SL (vs. longer than $10 \%$ of SL).

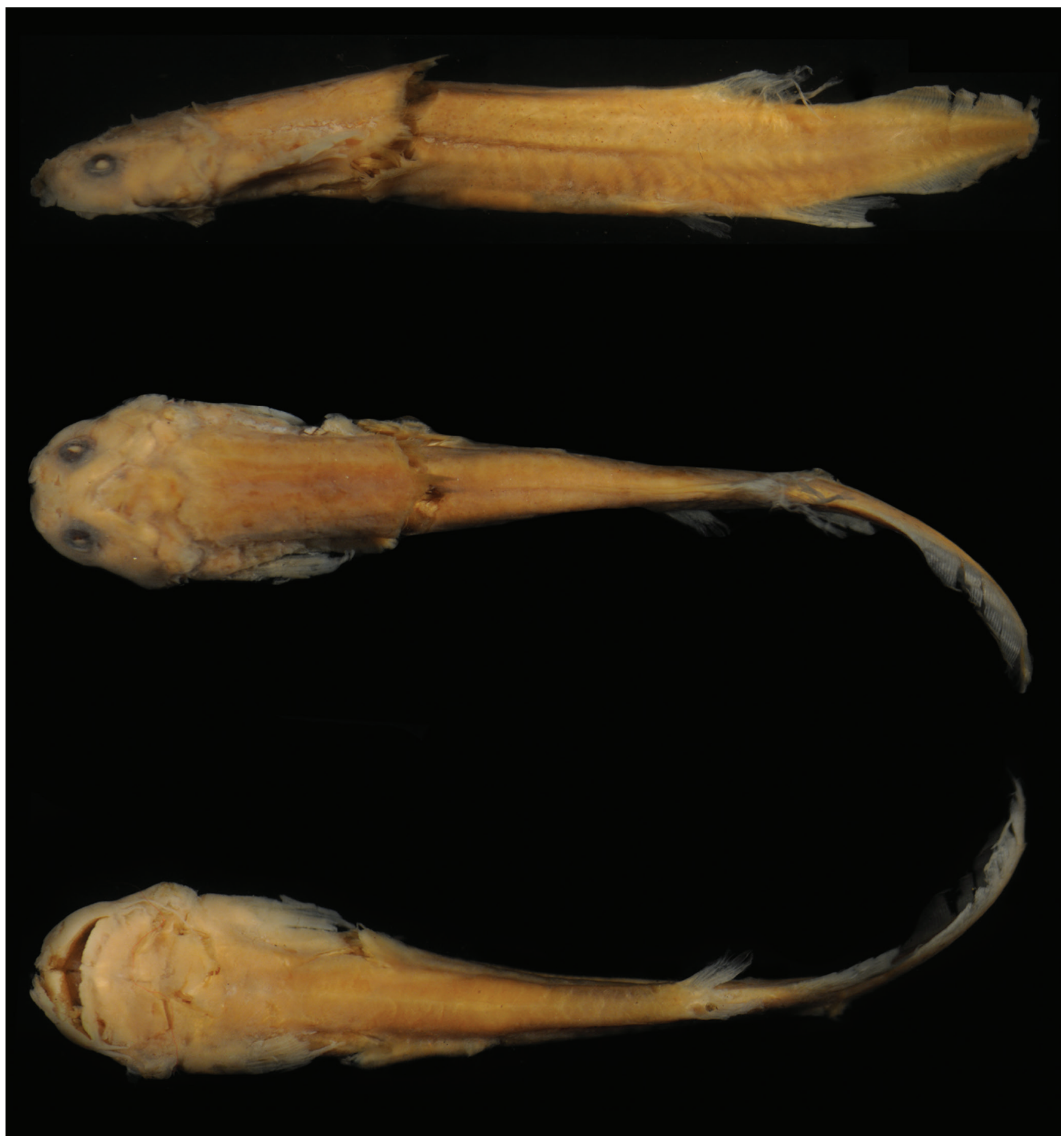

Fig. 1. Ochmacanthus batrachostoma, holotype, MNRJ 786 (29.15 mm SL), Brazil, Mato Grosso, Corumbá, rio Paraguai at São Luiz de Cáceres. 
Description. Morphometric data are presented in Table 1.

Body relatively elongate, depressed in cross section close to head and gradually more compressed towards tail. Dorsal body profile nearly straight on head, gently convex until end of dorsal fin and straight on caudal region, exclusive of accessory caudal rays. Ventral body profile gently convex until origin of anal fin and straight along caudal region, exclusive of accessory caudal rays. Body deepest at origin of dorsal fin. Dorsal and ventral profiles of caudal peduncle extremely expanded on proximal half, due to presence of well-developed procurrent caudal-fin rays and gradually less deep on distal half. Caudal peduncle profile exclusive of procurrent rays conical, with extremely fine tip, its depth approximately one fifth that at base. Head profile not perfectly continuous with trunk due to presence of opercular patch of odontodes. Myotomes visible along almost whole body, most prominently along posterior portion of trunk.

Head broad and semicircular in dorsal view, depressed in lateral view. Length nearly equal to width. Snout short and rounded anteriorly. Mouth inferior, as broad as head, its corners directed posteriorly, forming sucker-like semicircular disc. Lower lip forming broad continuous arc not divided in right and left halves, its postero-lateral folds short and strongly flattened against head. Upper lip forming broad continuous arc. Numerous small lumps present on internal surface of lower and upper lips. Jaw teeth extremely numerous. Upper jaw with 3 complete convex rows of teeth and another 3 incomplete and irregular rows medial to complete rows. Upper jaw teeth conical, long, thin and sinuous. Lower jaw teeth in 2 or 3 anterior incomplete rows and 2 posterior complete ones. Number of teeth of incomplete rows increasing posteriorly, with first and second rows very small (maximum 10 teeth each) and third surpassing the midpoint of complete row. Lower jaw teeth arched and directed laterally. Total number of teeth in excess of two hundred on both upper and lower jaws, all attached to respective bone. Branchiostegal membranes united to isthmus along its entire ventral region, laterally forming free fold of short length. Eyes round and located dorsally, their surface continuous with that of remainder of head. Interopercle with 8-12 small claw-like odontodes, arranged in 2 rows. Interopercular fold of skin thick and long. Opercular patch of odontodes with 8-12 odontodes in roundish arrangement, shaped similarly to those on interopercle. Gill opening extending from ventral margin of opercular odontode patch to median portion of interopercular odontode patch.

Table 1. Morphometrics of Ochmacanthus batrachostoma and a juvenile of $O$. alternus, FMNH 99611. Range values of $O$. batrachostoma are for holotype and non-type material.

\begin{tabular}{|c|c|c|c|c|c|c|}
\hline \multirow{2}{*}{ Measurement } & \multicolumn{4}{|c|}{ Ochmacanthus batrachostoma } & \multicolumn{2}{|c|}{ Juvenile of Ochmacanthus alternus } \\
\hline & $\mathrm{N}$ & Holotype & Range & Mean & $\mathrm{N}$ & Values \\
\hline Standard length $(L s ; \mathrm{mm})$ & 28 & 29.15 & $24.60-31.35$ & 28.16 & 1 & 16.37 \\
\hline \multicolumn{7}{|c|}{$\% L s$} \\
\hline Predorsal length & 28 & 61.58 & $58.72-66.18$ & 61.87 & 1 & 65.55 \\
\hline Caudal peduncle length & 28 & 25.21 & $25.21-31.08$ & 28.18 & 1 & 32.01 \\
\hline Body depth & 28 & 9.74 & $7.18-9.28$ & 8.18 & 1 & 23.58 \\
\hline Caudal peduncle depth & 28 & 8.23 & $8.23-12.00$ & 10.16 & 1 & 19.43 \\
\hline Dorsal fin length & 27 & & $11.57-16.53$ & 13.29 & 1 & 22.60 \\
\hline Head length $(L h)$ & 28 & 15.13 & $15.13-18.91$ & 17.11 & 1 & 30.30 \\
\hline \multicolumn{7}{|c|}{$\% L h$} \\
\hline Head width & 28 & 100.94 & $89.68-107.60$ & 99.85 & 1 & 91.33 \\
\hline Head depth & 28 & 43.62 & $41.08-53.52$ & 45.69 & 1 & 64.31 \\
\hline Maxilarry barbel length & 28 & 53.29 & $44.95-68.39$ & 53.89 & 1 & 90.93 \\
\hline Rictal barbel length & 28 & 23.36 & $23.36-38.62$ & 32.46 & 1 & 64.52 \\
\hline Breadth of mouth & 28 & 70.30 & $58.32-73.98$ & 69.00 & 1 & 64.72 \\
\hline Snout length & 28 & 27.07 & $23.82-31.61$ & 28.59 & 1 & 50.60 \\
\hline Horizontal length of eye & 28 & 27.05 & $20.18-29.33$ & 25.56 & 1 & 46.77 \\
\hline
\end{tabular}


Maxillary barbel thin and long, reaching origin of pectoral fin. Rictal barbel extending to slightly beyond midlength of maxillary one. Rictal barbel inserted almost entirely on postero-lateral fold of lower lip. Internal cartilage-like cores present in both barbels. Nasal barbels absent.

Nares large and conspicuous. Anterior nares directed dorsally and surrounded by a prominent flange of integument. Posterior nares larger than anterior ones, widely open, elliptic with posterior depression on flange. Posterior internarial width much smaller than anterior internarial width, slightly shorter than interorbital width.

Sensory cephalic pores s1 and s2 of supraorbital channel located between anterior and posterior nares, on small protuberance of skin. Pore s3 slightly posterior to eyes. Pore of infraorbital canal positioned between eyes and interopercle. Pore of preopercle canal immediately anterior to opercular odontodes. Lateral line short, not surpassing one third of trunk length and with only three pores. First lateral-line pore near posterodorsal margin of opercular odontode patch, second immediately dorsal to axillary gland, and third posterior to second.

Pectoral fin with 6 rays, first unbranched and slightly shorter than those following. Pectoral-fin origin located low on trunk, at horizontal through interopercular odontodes. Axillary gland forming large sack with thin distal tip and large pore on anterior half, located immediately posterior to pectoral-fin origin. Pelvic fin with 5 rays, first unbranched. Distal tip of pelvic fin not reaching anal-fin origin. Pelvicfin origin slightly anterior to vertical through dorsal-fin origin. Pelvic splint absent. Dorsal-fin rays 8 (20; dorsal fin damaged in holotype) or 9 (8), first two rays unbranched, shorter and thinner than those following, except eighth and ninth. Two or three small procurrent rays at anterior of dorsal fin. Anal-fin rays 9 (28), first two unbranched, shorter and thinner than those following, except eighth and ninth. Two (9) or three (19) small procurrent rays at anterior of anal fin. Caudal fin small, parabolic in lateral view. Principal caudal rays 5/6 (20; holotype) or 5/7 (8) always with fourth and fifth longest. Caudal-fin procurrent rays 58 (2), 60 (23; holotype) or 61 (3) dorsally and 58 (25; holotype) or 59 (3) ventrally. Procurrent rays well-developed, increasing in length until slightly anterior to middle of series and then gradually shorter to caudal-fin origin, making entire caudal region trowel-like. First complete haemal arch on sixth (2) or seventh (1) post-Weberian vertebra; Post-Weberian vertebrae 44 (1), 46 (10), 47 (13; holotype) or 48 (5). Ribs 2 (left side of two specimens, right side of one specimen) or 3 (both sides of 25 specimens).

Pharyngeal dentition composed of 4-6 small teeth on fifth ceratobranchial and 16-17 on dorsal pharyngeal toothplate.

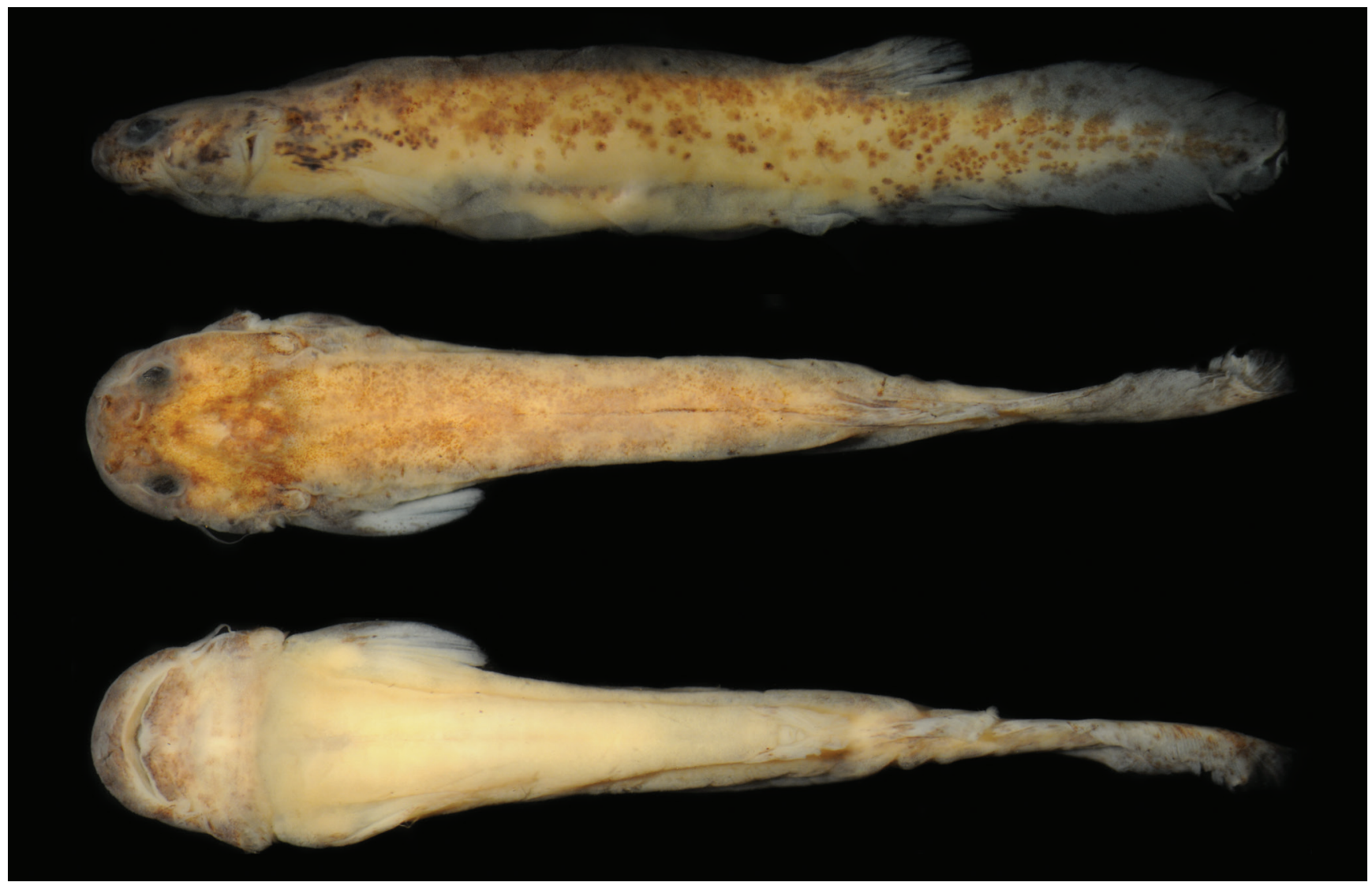

Fig. 2. Ochmacanthus batrachostoma, MZUSP 59340 (25.25 mm SL), Brazil, Mato Grosso do Sul, Corumbá, dead arm of Abobral 3. 
Color in alcohol. Overall body color light tan, becoming slightly darker on dorsal portion. Ventral surface mostly white, except for few chromatophores forming thin bifurcated line near pectoral girdle and some chromatophores on pelvic-fin base. Sides of body covered with brown blotches, forming poorly defined longitudinal stripes mainly on caudal peduncle. Lateral brown blotches coalesce mainly on anterior portion of body.

Overall color of head similar to that of body. Middorsal region of head, corresponding to central portion of neurocranium, darker and more uniformly colored. Conspicuous brown blotches present below each eye and on preopercular region. Snout darker than rest of head. Ventral surface of head with many chromatophores concentrated on lips. Median portion of lower lip white. Upper lip uniformly pigmented. Interopercular and opercular patch of odontodes darkly-pigmented. Maxillary and rictal barbels white. Pectoral-fin base dark, with dark chromatophores extending along first ray. Pelvic fins almost totally white, with only one or two chromatophores at base. Dorsal fin with few scattered chromatophores on basal half, denser distally. Anal fin pigmented at base with few scattered chromatophores between fin rays. Dorsal caudal-accessory rays with irregular fields of chromatophores. Ventral caudalaccessory rays with sparse chromatophores scattered on basal half. Caudal fin with dark line at median portion and scattered brown chromatophores concentrated on distal half.

Sexual dimorphism. None detected.

Distribution. Endemic to, and widely distributed in, the Paraná-Paraguai drainage, in Argentina, Brazil and Paraguay. Absent from the Upper Paraná and from the Prata drainage (Fig. 3).

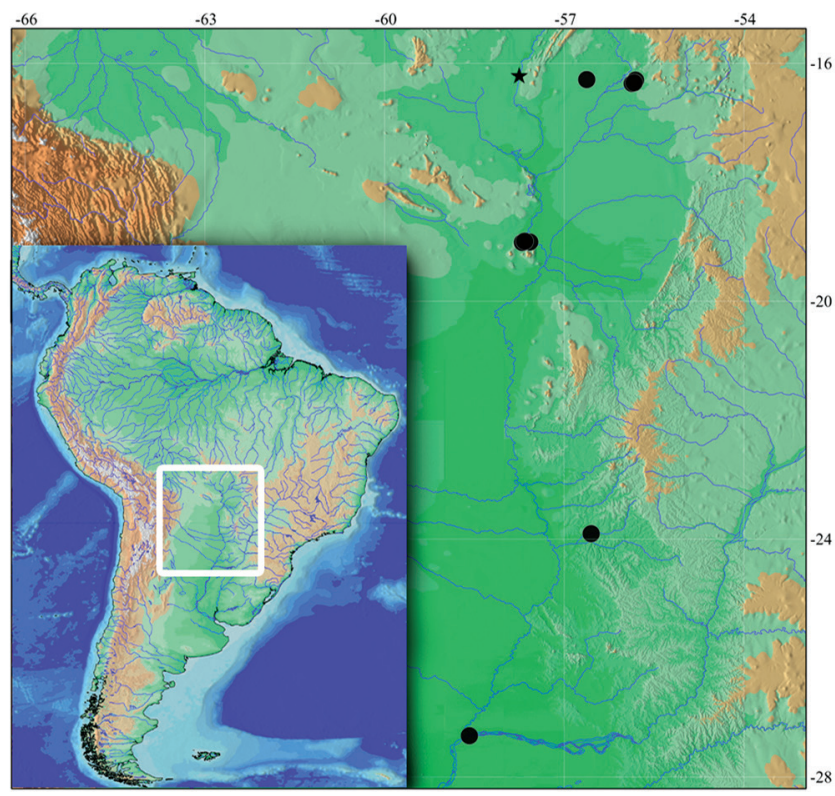

Fig. 3. Geographic distribution of Ochmacanthus batrachostoma (black star, holotype; black circle, non-type material).
Conservation status. Not present in any national or international lists of threatened species. According to the International Union for Conservation of Nature (IUCN) categories and criteria (IUCN Standards and Petitions Subcommittee, 2014), Ochmacanthus batrachostoma can be classified as Least Concern (LC).

Material examined. Total of 28 specimens. Holotype. MNRJ 786, Mato Grosso, Cáceres, rio Paraguai, $16^{\circ} 13^{\prime} \mathrm{S} 5^{\circ} 45^{\prime} \mathrm{W}, 1$, $29.2 \mathrm{~mm}$ SL. Non-type. Argentina. SMF 9012, Corrientes, Paso de la Patria, 1, 30.3 mm SL. Brazil. MNRJ 15399, Mato Grosso, Cáceres, Baía do Campo, district of Porto Esperidião,1 alc., 28.7 mm SL; MZUSP 95012, Mato Grosso, Barão do Melgaço, rio Paraguai drainage, rio Mutum 16²19'30"S 5549'59”W, 5, 1 c\&s, 26.4-27 mm SL; MZUSP 59678, Mato Grosso do Sul, Corumbá, rio Paraguai drainage, rio Abobral 2, 1, $27 \mathrm{~mm} \mathrm{SL}$; MZUSP 59340, Mato Grosso do Sul, Corumbá, rio Abobral 3, braço morto, 7, 17.6-25.4 mm SL; MZUSP 36351, Mato Grosso do Sul, Corumbá, Ladário, CODRASA, 3, 27-29.7 mm SL; MZUSP 42150, Mato Grosso, Barão de Melgaço, Barra de Sá Mariana, rio Mutum, 1, $26.1 \mathrm{~mm}$ SL; MZUSP 38183, Mato Grosso, Poconé, rio Pixaim, 2, 24.7-25.4 mm SL; NUP 2879, Mato Grosso, Chacororé, 6, 27-29.4 mm SL; ANSP 174744, without locality, 1, 1 c\&s, 23-23.6 mm SL. Paraguay. UMMZ 206670, San Pedro 2354'30”S 56³3'W, 1, 31 mm SL.

\section{Discussion}

There is some uncertainty about the limits and validity of the various Ochmacanthus species. The taxonomic descriptions are all old and based on limited material, and therefore lack information on intraspecific variation and detailed morphology. Material representing Ochmacanthus is nowadays extremely abundant in museums. The geographic distribution of the genus is now known to be vastly broader than when its constituent nominal species were first described. Examination of new material and attempts at identification readily reveal many forms that do not obviously match the existing descriptions, demonstrating the inadequacies of the available taxonomy of Ochmacanthus and that the genus is clearly in need of revisionary work. Despite that, no reasonable doubt remains about the validity of Ochmacanthus batrachostoma, the most distinctive species in the genus. Characters included in the diagnosis above clearly differentiate the species from its congeners by qualitative and quantitative traits.

Two of those characters deserve further discussion: the long rictal and maxillary barbels and the tadpolelike caudal region. Such traits, while diagnostic to $O$. batrachostoma, resemble conditions seen in juveniles of other species in the Stegophilinae-Vandelliinae clade. Normally, adults of species in that clade have short or very short maxillary and rictal barbels that clearly differ from the long barbels typical of other trichomycterids. Juveniles of Stegophilinae and Vandelliinae, however, seem to have much longer barbels than their respective 
adults. Unfortunately, juveniles of those two subfamilies are exceedingly rare in collections. We have been able to locate and examine only two samples (Ochmacanthus alternus, FMNH 99611 and Vandellia cirrhosa, UCV 3120) which contain such juveniles. In both cases, the maxillary and rictal barbels are proportionally longer than in their respective adults. Although any conclusive discussion will require a more detailed analysis of the relative barbel length in various parasitic and non-parasitic trichomycterids, as well as additional material representing juveniles across various clades, it is likely that a shortening of the maxillary and rictal barbels in adults is synapomorphic for the Stegophilinae plus Vandelliinae. The long condition in adult $O$. batrachostoma is a specialization of that species and perhaps associated with some degree of paedomorphosis.
Along the same line, we have observed that the caudal peduncle of a juvenile specimen of Ochmacanthus alternus (13.5 mm SL, FMNH 99611, Table 1) in the region bearing procurrent rays is proportionally larger than in adult specimens of that species, resembling the condition in adult O. batrachostoma (Fig. 4). Such ontogenetic evidence, in combination with the small body size of $O$. batrachostoma relative to congeners and other stegophilines, suggests a case of developmental truncation in that species. If confirmed, this will be the first case of paedomorphosis in the subfamily Stegophilinae. The degree of possible paedomorphosis in O. batrachostoma, however, is not be as extreme as that known in other trichomycterids such as in species of Ammoglanis, Trichomycterus anhanga and several glanapterygines (de Pinna 1989; Schaefer et al., 2005; Dutra et al., 2012).

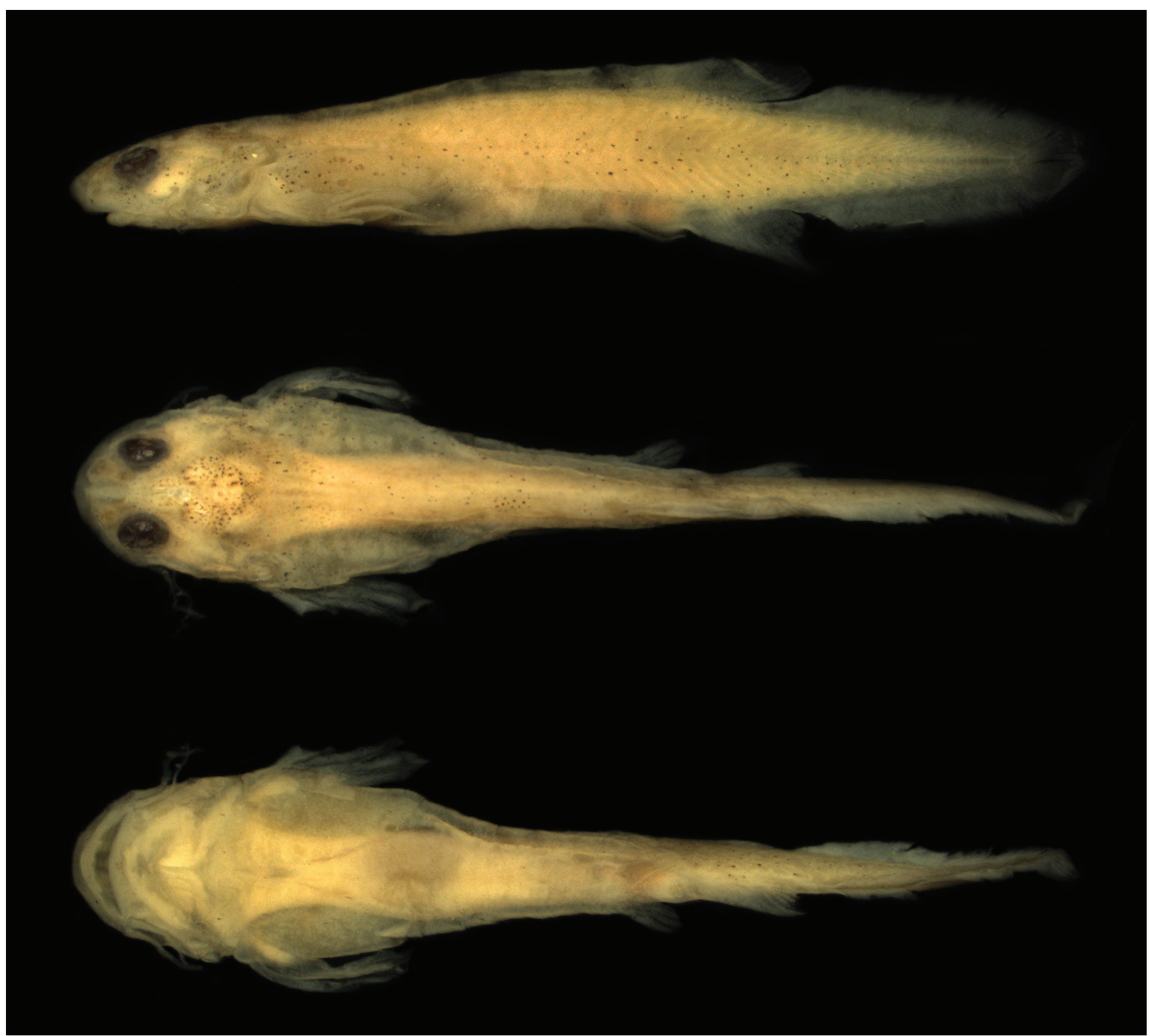

Fig. 4. Juvenile of Ochmacanthus alternus, FMNH 99611 (13.50 mm SL), Ecuador, Napo, tributary of Shusshufindi River. 
Comparative material examined. Total of 133 specimens. Ochmacanthus alternus: Brazil: MZUSP 30474, Amazonas, rio Negro, Anavilhanas, Igapó, 3, 47.5-48.2 mm SL; MZUSP 30464, Roraima, Rio Branco, Lake of Maguari, 3, 45.6-53 mm SL; MZUSP 30463, Roraima, Rio Branco, Marará, 7, 31.4-56.6 mm SL. Colombia: UF 26139, Meta, Yucao, 7, 28.2-35.1 mm SL. Ecuador: FMNH 99611, Napo, tributary of Shusshufindi River, 4, 13.5-35.3 mm SL. Guyana: SMF 4984, Litany ou tampoc, Criquet, 1, $34.3 \mathrm{~mm}$ SL; ANSP 175853, 04³0'16”N 58³1'38'W, 3, 40.644.4 mm SL; ROM.ICH 61980, Shimiri (Yawiri) Creek. Kurupukari downriver, 1, $51.5 \mathrm{~mm}$ SL. Venezuela: UCV 16328, 11, 2 c\&s, 33.640.5 mm SL; MZUSP 48109, Portuguesa, Caño Maraca, 8²5’30”'N 69²7'40”W, 10, 27.5-30.7 mm SL; UCV 77812, Bolívar, Tabaro River at Camp Dedemai, 1, $28.4 \mathrm{~mm}$ SL. Ochmacanthus orinoco: Brazil: MZUSP 24160, Pará, rio Tocantins, Lagoon near Channel Capitariquara, near Jatobal, 4, 1 c\&s, 20.4-34.6mm SL; MZUSP 113696, Roraima, Caracaraí, rio Negro drainage, rio Jufari, Paricá Beach, 1'8'41'S 6159'57'W, 8, 31.7-34.3 mm SL; MZUSP 30478, Amazonas, rio Negro drainage, rio Arirará, 2, 25.1-27.1 mm SL. Venezuela: MZUSP 106069, Portuguesa, Orinoco, rio Bocono, 2, 33.8-38.6 mm SL; FMNH 105575, Orinoco River, 5h upstream of Atapabo, 1, 31.6 mm SL; UCV 23041, 8, 37.9-40.1 mm SL; UCV 53071, 8, 2 c\&s, 31.3-44 mm SL. Ochmacanthus reinhardtii: Brazil: MZUSP 94362, Mato Grosso, Gaúcha do Norte, rio Xingú drainage, marginal lagoon rio Culuene, 13³0'51'S 5305'49' W, 15, 19.1-39 mm SL; MZUSP 94145, Mato Grosso, Gaúcha do Norte, rio Xingu drainage, rio Culuene, $13^{\circ} 30^{\prime} 53^{\prime} \mathrm{S}$ 5305'40' $\mathrm{W}, 5$, 20-33.9 mm SL; MZUSP 72876, Roraima, rio Branco drainage, tributary of rio Bem Querer, Bem Querer Waterfall, 1, 25 mm SL; INPA 4163, Maranhão, rio Xingu, Bobaquara Island, 7, 20.7-26.8 mm SL; INPA 4121, Pará, Arroz Cru, rio Xingu, Palmeiras Beach, 5, 1 c\&s, 27.1-32.5 mm SL. Guyana: ROM-ICH 61981, 1, 43.5 mm SL; ROM-ICH 61977, 1, 1 c\&s, 33.5-43mm SL; ROM-ICH 61969, 1, 41 mm SL; ROM-ICH 61976, 2, 29-32 mm SL; ROM-ICH 61975, 1, 31 mm SL; ROM-ICH 61972, 1 , 35 mm SL. Suriname: USNM 225897, Nickerie, Corantijn River drainage, $03^{\circ} 36^{\prime} \mathrm{N} 57^{\circ} 37^{\prime} \mathrm{W}, 3$, 33.2-42.2 mm SL; USNM 225896, Nickerie, Corantijn River drainage, $03^{\circ} 35^{\prime} \mathrm{N} 5^{\circ} 39^{\prime} \mathrm{W}, 2,1$ c\&s, 42.1-45.5 mm SL; USNM 225899, Nickerie, Corantijn River drainage, $03^{\circ} 42^{\prime} \mathrm{N} 57^{\circ} 42^{\prime} \mathrm{W}, 2$, 48.7-48.8 $\mathrm{mm}$ SL.

\section{Acknowledgements}

We are grateful to Dr. John G. Lundberg (ANSP), Dr. Caleb McMahan (FMNH), Dr. Paulo A. Buckup (MNRJ), Dra. Carla S. Pavanelli (NUP), Dr. Hernán L. Fernández (ROM-ICH), Dr. Friedhelm Krupp (SMF), Dr. Francisco Provenzano (UCV), Dr. Wiliam Fink (UMMZ) and Dr. Dave Johnson (USNM) for granting access to study material used in this study. We are grateful to Prof. Dr. Flávio Bockmann from Universidade de São Paulo, Ribeirão Preto, Brazil, for granting access to radiographs used in this study. Research associated with this paper was part of a MSc Dissertation by the first author at the Graduate Program in Systematics, Animal Taxonomy and Biodiversity of the Museu de Zoologia, Universidade de São Paulo. Funding was provided by FAPESP and CNPq.

\section{References}

Adriaens, D., J. N. Baskin \& H. Coppens. 2010. Evolutionary morphology of trichomycterid catfishes: about hanging on and digging in. Pp. 337-362. In: Nelson J. S., H. -P Schultze \& M. V. H. Wilson (Eds.). Origin and phylogenetic interrelationships of teleosts. München, Verlag Dr. Friedrich Pfeil.

Arratia, G. \& L. Huaquin. 1995. Morphology of the lateral line system and of the skin of diplomystid and certain primitive loricarioid catfishes and systematics and ecological considerations. Bonn, Zoologisches Forschungsinstitut und Museum Alexander Koenig, 110. (Bonner Zoologische Monographien, no. 36).

Baskin, J. N. 1973. Structure and relationships of the Trichomycteridae. Unpublished Ph. D. Dissertation, City University of New York, New York, 389p.

Datovo, A. \& M. C. C. de Pinna. 2014. A new species of Ituglanis representing the southernmost record of the genus, with comments on phylogenetic relationships (Teleostei: Siluriformes: Trichomycteridae). Journal of Fish Biology, 84: 314-327.

DoNascimiento, C. L. 2015. Morphological evidence for the monophyly of the subfamily of parasitic catfishes Stegophilinae (Siluriformes, Trichomycteridae) and phylogenetic diagnoses of its genera. Copeia, 2015(4): 933-960.

DoNascimiento, C. L. 2013. Sistemática y relaciones filogenéticas de la subfamília de bagres parásitos Stegophilinae (Siluriformes, Trichomycteridae). Unpublished Ph.D. Thesis, Facultad de Ciencias, Universidad Central de Venezuela, Caracas, 337p.

DoNascimiento, C.L.\& F. Provenzano. 2006. The genus Henonemus (Siluriformes: Trichomycteridae) with a description of a new species from Venezuela. Copeia, 2006(2): 198-205.

Dutra, G. M., W. B. Wosiacki \& M. C. C. de Pinna. 2012. Trichomycterus anhanga, a new species of miniature catfish related to T. hasemani and T. johnsoni (Siluriformes: Trichomycteridae) from the Amazon basin, Brazil. Neotropical Ichthyology, 10: 225-231.

Eigenmann, C. H. 1912. The freshwater fishes of British Guiana, including a study of the ecological grouping of species, and the relation of the fauna of the plateau to that of the lowlands. Memoirs of the Carnegie Museum, 5: xvii, 578 pp., 103 pls.

Eigenmann, C. H. 1918. The Pygidiidae, a family of South American catfishes. Memoirs of the Carnegie Museum, 7: 259-398.

Eschmeyer, W. N. \& J. D. Fong. 2014. Catalog of fishes: genera, species, references. Eletronic version. San Francisco, CA, California Academy of Sciences. Available from: http:// researcharchive.calacademy.org/research/ichthyology/catalog/ SpeciesByFamily.asp. (30 Jan 2012).

Fernández, L. \& S. A. Schaefer. 2009. Relationships among the Neotropical candirus (Trichomycteridae, Siluriformes) and the evolution of parasitism based on analysis of mitochondrial and nuclear gene sequences. Molecular Phylogenetics and Evolution, 52: 416-423.

International Union for Conservation of Nature (IUCN). Standards and Petitions Subcommittee. 2014. Guidelines for using the IUCN Red List Categories and Criteria. Version 11. Prepared by the Standards and Petitions Subcommittee. Glard, Switzerland, IUCN, 87 p. Available from: http:/www.iucnredlist.org/ documents/RedListGuidelines.pdf. ( 14 Sep 2015).

Koch, W. R. 2002. Revisão taxonômica do gênero Homodiaetus (Teleostei, Siluriformes, Trichomycteridae). Iheringia, Série Zoologia, Porto Alegre, 92: 33-46. 
Leung, T. L. F. 2014. Fish as parasites: an insight into evolutionary convergence in adaptations for parasitism. Journal of Zoology, 294: 1-12.

Machado, F. A. \& I. Sazima. 1983. Comportamento alimentar do peixe hematófago Branchioica bertonii (Siluriformes, Trichomycteridae). Ciência e Cultura, 35: 344-348.

de Pinna, M. C. C. de. 1989. A new sarcoglanidine catfish, phylogeny of its subfamily, and an appraisal of the phyletic status of the Trichomycterinae (Teleostei, Trichomycteridae). American Museum Novitates, 2950:1-39.

de Pinna, M. C. C. de. 1998. Phylogenetic relationships of Neotropical Siluriformes (Teleostei: Ostariophysi): historical overview and synthesis of hypotheses. Pp. 279-330. In: Malabarba, L. R., R. E. Reis, R. P. Vari, Z. M. S. Lucena \& C. A. S. Lucena. (Eds.). Phylogeny and Classification of Neotropical Fishes. Porto Alegre, Edipucrs,.

de Pinna, M. C. C. de \& H. A. Britski. 1991. Megalocentor, a new genus of parasitic catfish from the Amazon basin: the sister group of Apomatoceros (Trichomycteridae: Stegophilinae). Ichthyological Exploration of Freshwaters, 2: 113-128.

de Pinna, M. C. C. de \& W. Wosiacki. 2003. Family Trichomycteridae (Pencil or parasitic catfishes). Pp. 270-290. In: Reis, R. E., S. O. Kullander \& C. J. Ferraris Jr. (Orgs.). Check list of the freshwater fishes of South and Central America. Porto Alegre, Edipucrs.

Myers, G. S. 1927. Descriptions of new South American freshwater fishes collected by Dr. Carl Ternetz. Bulletin of the Museum of Comparative Zoology, 68: 107-135.

Ribeiro, A. M. 1912. Loricariidae, callichthyidae, doradidae e trichomycteridae. Rio de Janeiro, (Publicação Commissão de Linhas Telegraphicas Estrategicas de Matto-Grosso ao Amazonas; [n $\left.\mathrm{n}^{\mathrm{O}} 16\right]$, anexo no. $5^{\circ}$ - História Natural Zoologia). 31p.
Santos Neto, C. 2014. Sistemática do gênero Ochmacanthus: um grupo de bagres neotropicais lepidófagos (Teleostei: Siluriformes: Trichomycteridae). Unpublished Masters Dissertation. Universidade de São Paulo, São Paulo, 240p.

Schaefer, S. A., F. Provenzano, M. de Pinna \& J. N. Baskin. 2005. New and noteworthy Venezuelan glanapterygine catfishes (Siluriformes, Trichomycteridae), with discussion on their biogeography and psammophily. American Museum Novitates, 3496:1-27.

Taylor, W. R. \& G. C. Van Dyke. 1985. Revised procedures for staining and clearing small fishes and other vertebrates for bone and cartilage study. Cybium, 9: 107-119.

Tchernavin, V. V. 1944. A revision of some Trichomycterinae based on material preserved in the British Museum (Natural History). Proceedings of the Zoological Society of London, 114: 234-275.

Zuanon, J. \& I. Sazima. 2004. Vampire catfishes seek the aorta not the jugular: candirus of the genus Vandellia (Trichomycteridae) feed on major gill arteries of host fishes. Aqua, Journal of Ichthyology and Aquatic Biology, 8: 31-36.

Zuanon, J. \& I. Sazima. 2005. Free meals on long-distance cruisers: the vampire fish rides giant catfishes in the Amazon. Biota Neotropica, 5: 109-114.

Winemiller, K. O. \& H. Y. Yan. 1989. Obligate mucus-feeding in a South American trichomycterid catfish (Pisces: Ostariophysi). Copeia, 1989(2): 511-514.
Submitted March 25, 2015

Accepted December 28, 2015 by Brian Sidlauskas 